Mai, N. K., Nguyen, A. K. T., \& Nguyen, T. T. (2021). Implementation of Corporate Social Responsibility Strategy to Enhance Firm Reputation and Competitive Advantage. Journal of Competitiveness, 13(4), 96114. https://doi.org/10.7441/joc.2021.04.06

\title{
Implementation of Corporate Social Responsibility Strategy to Enhance Firm Reputation and Competitive Advantage
}

\author{
- Ngoc Kbuong Mai, An Khoa Truong Nguyen, Thanb Thuy Nguyen
}

\begin{abstract}
Corporate social responsibility (CSR) is an important strategy for firms to gain a positive reputation. This study aims to identify the mediating role of firm reputation on the relationships of CSR dimensions (economic, legal, ethical, philanthropic and environmental) and competitive advantage, and how a firm directly gains competitive advantage through CSR implementation. Data were collected by surveying 869 managers, as representatives of small and medium enterprises, and large enterprises, in the trade and service, real estate and manufacturing sectors in Vietnam. Then, SmartPLS 3.0 software and the partial least squares structural equation modelling method were used to process the data and test the hypotheses. The empirical results are impactful and enhance the existing literature on strategic management. The results show that implementing environmental, ethical, philanthropic and legal CSR activities contribute positively to increase the firm reputation and thus generating competitive advantage. The findings indicate that the implementation of economic CSR activities does not enable firms to gain a reputation. In contrast, active involvement in environmental CSR activities results in building firm reputation, thereby creating a source of competitive advantage for firms. The study provides guidelines for top-level management to adjust their CSR strategies more effectively to improve reputation and competitive advantage.
\end{abstract}

Keywords: corporate social responsibility, small and medium enterprises, firm reputation, firm competitive advantage

JEL Classification: G30, M14

Received: July, 2021

1st Revision: December, 2021

Accepted: December, 2021

\section{INTRODUCTION}

Stakeholders have been placing greater emphasis on organisations' responsibilities to integrate social and environmental concerns in their operations (Kim et al., 2020). The global social and environmental challenges caused by the coronavirus disease (COVID-19) pandemic have compelled firms to conduct CSR activities (He \& Harris, 2020). In developing countries, particularly Vietnam, an increase in environmental catastrophes, such as climate change, 
specifically the sea-level rise in the Mekong River Delta, has become more serious. This has led to the implementation of CSR in business operations in Vietnam in particular and developing countries in general; thus, CSR has become more crucial and urgent than ever (Jamali \& Karam, 2018). However, numerous firms in these countries, particularly small and medium enterprises, have typically applied CSR into their operations without a primary motivator. Therefore, many studies have investigated the relationships between CSR implementation and business outcomes (Islam et al., 2021; Javed et al., 2020; Kowalczyk \& Kucharska, 2020; Zhang et al., 2020) to encourage firms to actively engage in CSR activities. Under a highly competitive market, firms need to find resources for creating a competitive advantage. CSR is a source of a competitive advantage that has recently received academic research interest (Cegliński \&Wiśniewska, 2016; Saeed \& Arshad, 2012). However, the impacts of CSR on competitive advantage remain contradictory (Nyuur et al., 2019). Some studies found a positive relationship (Ahn et al., 2021; Saeidi et al.,2015; Zhang et al., 2020); some found a negative or no relationship (Nelling \& Webb, 2009, Yu et al., 2017). Walker et al. (2019) pointed out the importance of investigating how CSR create values in different contexts. To clarify these issues, this research aims to study the impact of CSR on competitive advantage with a mediating role of reputation in a developing country. Notably, researchers have attempted to identify the role of CSR in building firm reputation (Park, 2019). According to Islam et al. (2021), Melo \& Garrido-Morgado (2012), Porter \& Kramer (2006) and Zhu et al. (2014), it is an important strategic resource because it can create a competitive advantage. Melo \& Garrido-Morgado (2012) proposed that CSR is a strategic initiative that contributes to a firm reputation; hence, it can generate a competitive advantage. Moreover, Islam et al. (2021) suggested that firms integrate CSR into their business strategy to foster a competitive advantage. However, a significant research gap remains-measuring the connections among CSR dimensions (economic, legal, ethical, philanthropic and environmental), firm reputation and firm competitive advantage, and the effects of these constructs on each other in the context of developing countries. In detail, this study hypothesises that a firm's reputation is the result of active engagement in CSR and mediates the relationship between CSR and competitive advantage. CSR dimensions are positively and directly associated with a firm's competitive advantage. The research is hoped to contribute to the existing literature review of strategic management.

\section{THEORETICAL BACKGROUND}

\subsection{Theoretical framework}

The resource-based theory is one of the theories widely used to explain competitive advantage in strategic management. Barney (1991) explained resource-based theory referred to characteristics of valuable, rare, difficult to imitate, and no substitutable that resources have; the resources could be intangible and tangible assets of a firm (Wernerfelt,1995). These resources help firms create differentiation, which is considered a source of competitive advantage. The competitive advantage enables firms to outperform their competitors. Thus, it is important for firms to find out the sources of competitive advantage. CSR practices are a popular tool to create differentiation strategy (Chun \& Cho, 2017; McWilliams et al., 2006). CSR practices such as addressing environmental and social issues, meeting stakeholder requirements, contributing to 
societal development can create valuable intangible resources that differentiate firms from other competitors. Thus, implementing CSR practices leads to a competitive advantage in the long term. The resource-based view of the firm is also used to explain the relationships between CSR, reputation, and competitive advantage. Reputation is an intangible asset that is valuable and difficult to imitate (Husted \& Allen, 2007). Firm reputation is another source of competitive advantage, and this competitive advantage is strengthened by CSR implementation. In other words, both CSR and reputation are strategic resources that help to achieve a competitive advantage

\subsection{Corporate Social Responsibility Practices}

An extensive consensus among researchers is that CSR was conceptualised in four dimensions: economic, legal, ethical and philanthropic (Carroll, 1991). Although almost all of the mentioned studies refer to the well-known Caroll model (Carroll,1991), the model itself does not mention environmental CSR. Dahlsrud (2008) supplemented environmental responsibilities as an important dimension of CSR because of the growing concerns of stakeholders, including customers, employees and government, with environmental and social issues (Kowalczyk \& Kucharska, 2020). As a result, researchers must consider these five dimensions (economic, legal, ethical, philanthropic and environmental) consistently to define and evaluate the CSR concept (Dahlsrud, 2008).

According to Carroll (2016), economic CSR refers to the responsibility of the firm to create goods and services and make profits by adding value to products. These economic activities improve the operation of a business for sustainable growth and simultaneously comply with laws and ethical standards, such as philanthropic and environmental practices. He also defined legal CSR as obeying prescribed laws and regulations, including registration, documentation, employment and taxation. Ethical CSR aims to voluntarily protect fairness and justice and respect stakeholders' moral rights to satisfy social expectations and comply with higher standards prescribed by the legal system. Carroll (2016) also described philanthropic CSR as voluntary activities, such as donating firm resources to promote human and social welfare in the community. Corporations are required to perform economic and legal CSR but are expected and desired to engage in ethical and philanthropic CSR, respectively (Carroll,1991). Further, environmental CSR involves supporting the natural environment, such as using clean energy, producing environmentally friendly products and services, and recycling or 'doing business in an eco-friendly manner (Han et al., 2020).

\subsection{CSR and Firm Reputation}

Reputation is essential for the success of business organisations in today's competitive marketplace (Kim et al., 2018). Miles \& Covin (2000) referred to firm reputation as an indicator to measure the perceived level of credibility, trustworthiness, responsibility and reliability of that firm. Most stakeholders make their decision based on the firm reputation because it can make them believe and trust in that firm (Zhu et al., 2014). Researchers have indicated that a good reputation can benefit firms in both financial and non-financial ways. In terms of financial outcomes, a higher reputation results in a higher return on assets. Non-financial advantages of corporate reputation 
consist of the decline in employee's intentions to quit and burnout because of job insecurity (Ali et al., 2020), the increase in a corporate brand (Baalbaki \& Guzmán, 2016), brand equity and customer satisfaction (Heinberg et al., 2018). Many attempts have been made to improve the understanding of the relationship between CSR and firm reputation.

Several researchers have indicated that CSR is positively associated with a firm reputation (Islam et al., 2021; Park, 2019; Saeidi et al., 2015; Zhang et al., 2020). Fombrun (1996) reported that economic CSR is an important driver that influences a firm reputation. Firms are expected to provide customers with high-quality products and produce adequate profits for investors. As identified by Park et al. (2014), firms that fulfil economic responsibility can considerately achieve corporate reputation. Therefore, it is believed that when firms can meet the requirements of stakeholders in economic responsibilities, they will be able to build a strong reputation in the industry. Thus, the first hypothesis is presented as follows:

H1. Economic responsibility has positive effects on a firm reputation.

Carroll (1991) argued that firms must pursue their economic development within the legal framework. Earlier studies have revealed that legal responsibilities are important factors contributing significantly to boosting the reputation of firms (Branco \& Rodrigues, 2006; Park et al., 2014). Park et al. (2014) stated a direct positive effect of legal CSR on a firm reputation. This is because reputation is about how stakeholders perceive a firm as reliable or trustworthy. Therefore, performing legal responsibility is essential to maintaining and building a good reputation. Accordingly, the following hypothesis has been developed:

H2. Legal responsibility has positive effects on a firm reputation.

Ethical issues related to labour rights, selling unsafe products or engaging in 'sweatshop' manufacturing result in stakeholder pressure (Lantos, 2001). Ethical CSR aims for the firm to perform in line with ethical, social standards and justifiable aspirations of the stakeholders, which may not be documented in laws. There is evidence that 'good ethics is good business' and, in the long term, can enhance firm reputation (Lantos, 2001). This is because firms are required to follow moral rules, and customers place high expectations on firms to behave ethically (Creyer, 1997); firms engaging in ethical CSR can increase customers' perceptions of the ethical activities of that firm (Zhang et al., 2020). These perceptions, according to Bendixen \& Abratt (2007), have a positive influence on a firm reputation. Thereby, ethical responsibilities may have a vital role in improving a firm reputation. Thus, the third hypothesis is presented:

H3. Ethical responsibility has positive effects on a firm reputation.

There is evidence that a firm's philanthropic activities are the critical driving factors of building its reputation (Muller \& Kräussl, 2011). Firms exercise philanthropic CSR by donating financial and non-financial resources to society to exhibit reciprocation and improve societal welfare. For example, some philanthropic activities, such as sharing food and shelter during natural disasters, have received critical acclaim from the community. Brammer \& Millington (2005) concluded that firms that contribute to society have better reputations. This is because stakeholders hold a more favourable impression of philanthropic firms (Brammer \& Millington, 2005), which can lead to goodwill and reputation for those firms. In line with this discussion, the following hypothesis is presented: 
H4. Philanthropic responsibility has positive effects on a firm reputation.

Environmental problems pressure the environmental responsibility of firms (Khojastehpour \& Johns, 2014). Firms conduct environmental responsibility by incorporating environmental issues into their operations without harming economic performance. Firms strive to not only decrease energy consumption but also to raise employees' awareness about environmental responsibilities (Öberseder et al., 2013). Customers show interest in firms that produce sustainable and environmental-friendly products (Öberseder et al., 2013; Van Beurden \& Gössling, 2008) because this makes them feel responsible for the environment. Therefore, firms performing environmental responsibility can satisfy these customer interests and help them create a good reputation among stakeholders (Ahn et al.,2021; Khojastehpour \& Johns, 2014). Hence, the following hypothesis is developed:

H5. Environmental CSR has positive effects on a firm reputation.

\subsection{CSR and Firm Competitive Advantage}

It is not easy to define competitive advantage as there are different perspectives on understanding the concept such as innovation, leadership, quality, differentiation (El-Garaihy et al., 2014). According to Barney (1991), competitive advantage occurs when a firm's strategy creates value that competitors cannot mimic or take advantage of, or firms need to create differentiation strategies to gain competitive advantage. The development of competitive advantage is crucial to business survival and development; thus, firms need to figure out their ways to create sustainable competitive advantage, which focus on improving capability and productivity (Hortoványi, 2016). CSR is considered a source of competitive advantage (Porter \& Kramer, 2006). A firm can strengthen its competitive advantage by investing in a CSR strategy (Ahn et al., 2021; Melo \& Galan, 2011; Porter \& Kramer, 2012; Saeidi et al.,2015; Zhang et al., 2020). Firms engaging in CSR activities give rise to firm performance via satisfied stakeholders (Javed et al., 2020). Further, Carroll \& Shabana (2010) stated that the pursuit of all CSR responsibilities allows firms to build a strong relationship with stakeholders, reduce turnover rates and attract qualified employees and potential customers; thereby, in the long term, they differentiate themselves from their rivals. To clarify the relationship between CSR and competitive advantage, the study examines how each type of CSR affects a competitive advantage.

Turker (2009) argued that economic CSR is the primary base for the establishment of firms. Indeed, generating profit is crucial for the survival of firms in a competitive environment because, without profits, the firm cannot maintain its operations and benefit stakeholders in the long term (Carroll, 2016). Since firms generate profits by adding value to benefit stakeholders, especially investors, the more a firm can create profits and benefit investors, the more satisfied investors are. Consequently, the more the business growth that the firm can achieve through reinvestment (Carroll, 2016). Furthermore, firms gain profits through improving products and attributes that enable customers to perceive the values of their products in comparison with competitors (Saeidi et al., 2014). In return, it generates a competitive advantage. Therefore, economic CSR can be a driver to sustain competitive advantage in the long term, which leads to the following hypothesis:

H6. Economic responsibility has positive effects on a firm competitive advantage. 
As a required responsibility, legal CSR is vital for firms because a firm is an entity itself and must obey laws and rules (Carroll, 1991). Branco \& Rodrigues (2006) showed that firms taking illegal actions could be subject to sanctions, consequently impeding them from operating and gaining profitability in the long term; thus, firms need to fulfil legal responsibilities to survive and be profitable. Moreover, Alvarado-Herrera et al. (2017) asserted that legal activities, such as ensuring that all products meet legal standards and respecting contractual agreements, are vital factors in CSR for firms to maintain and sustain their operation. He concluded that legal CSR positively affects building a competitive advantage for firms. It is plausible to suggest that a firm's strict compliance with laws can be considered a competitive advantage of that firm:

H7. Legal responsibility has positive effects on a firm competitive advantage.

In addition, Cacioppe et al. (2008) mentioned that ethical CSR plays a crucial role in social responsibility. As stakeholders (customers, employees) positively or negatively influencing a firm is essential for the fate of that firm, ethical behaviours, such as concern about the relationship between employees and community (Saeidi et al., 2015), help build commitment among employees in the firm. This is considered a source of competitive advantage (Collier \& Esteban, 2007). Further, customers regard firms as good citizens when they focus on philanthropic and ethical activities (Cacioppe et al., 2008); hence, firms can differentiate themselves from other rivals. Ahn et al. (2021) also stated that being a philanthropic and ethical citizen can help build a good CSR image. Moreover, El-Garaihy et al. (2014) indicated that philanthropic activities, such as active concern about the wellbeing of people by sponsoring education and charitable programmes or donating to people in need, generate competitive advantage for firms. Therefore, the hypotheses are presented:

H8. Ethical responsibility has positive effects on a firm competitive advantage.

H9. Philanthropic responsibility has positive effects on a firm competitive advantage.

Han et al. (2019) believed that environmental responsibility plays a fundamental role in the longterm development of firms. Customers expect firms to engage in environmental responsibility (Ahn et al., 2021) and are willing to pay higher prices for environmentally and socially conscious firms. This can lead to an increase in prices and volume sales, which can contribute to the profitability of firms (Khojastehpour \& Johns, 2014). Thus, firms that actively perform environmental activities can generate a competitive advantage (Mai, 2013). Khojastehpour \& Johns (2014) also provided support for the positive association among CSR, corporate reputation and competitive advantage. The alignment of environmental CSR with the reputation of firms and profitability is essential for sustained competitive advantage. Hence, firms that strive for environmental responsibility are likely to foster a competitive advantage (Yadav et al., 2017). As such, the following hypothesis has been developed:

H10. Environmental responsibility has positive effects on a firm competitive advantage.

\subsection{Firm Reputation and Firm Competitive Advantage}

Corporate reputation and competitive advantage are proved to have a linkage (Hur et al., 2014). In terms of strategy, corporate reputation is considered an intangible asset that contributes to the sustained competitive advantage of a firm (Fombrun et al., 2000). More importantly, Melo 
\& Garrido-Morgado (2012) argued that intangible assets, such as corporate reputation, are gained by participating in CSR activities, representing a potential path to sustained competitive advantage. Therefore, Zhu et al. (2014) recommended that managers should consider the interests of stakeholders to boost the reputation of firms; in the long term, this may generate a competitive advantage. El-Garaihy et al. (2014) showed the relationship between CSR dimensions, corporate reputation and competitive advantage. Based on the above discussion, the hypothesis is:

H11. Firm reputation has positive effects on a firm competitive advantage.

From the above hypothesis development, the research model presented in Figure 1 is proposed:

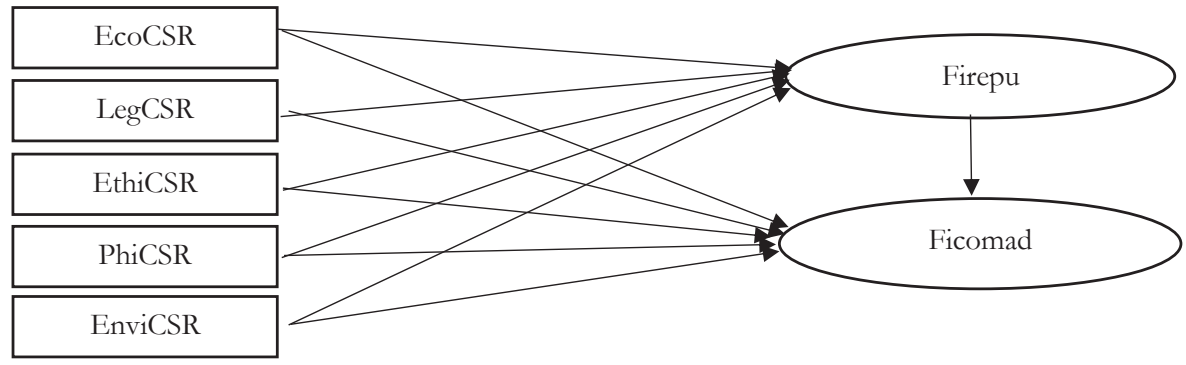

Fig. 1 - The research model. Source: own research

\section{RESEARCH OBJECTIVE, METHODOLOGY AND DATA}

This study was designed to test the hypotheses by addressing two specific aims: (1) to identify the mediating role of firm reputation in the link between CSR dimensions and competitive advantage; and (2) to identify the direct effect of CSR dimensions on gaining a competitive advantage.

\subsection{Data collection}

Data were collected through constructed questionnaires directly delivered to 896 owners, managers, deputy managers, assistant managers, chief accountants and legal managers of firms. These firms specialise in the trades and services, real estate and manufacturing sectors in Ho Chi Minh City (HCMC) and Binh Duong Province in Vietnam. A hard copy of the questionnaire was given directly to respondents and filled in by one representative in each company. Data collection was conducted within six months.

\subsection{Questionnaire design}

The questionnaire was divided into two parts. The first part asked demographic questions about participants. Demographic information included the position and sector of the participants, business type, annual revenue and location of the company. The second part contained questions assessing legal CSR, economic CSR, ethical CSR, philanthropic CSR, environmental CSR, firm reputation and competitive advantage. To ensure the validity of the content, measurement items were derived from previous studies and revalidated for this study. The scale of legal CSR was 
adapted from El-Garaihy et al. (2014) and Turker (2009). The items of economic CSR were mainly based on the study of Alvarado-Herrera et al. (2017). The ethical CSR construct was employed by El-Garaihy et al. (2014) and Turker (2009). The items of philanthropic CSR were adapted from Galbreath (2010) and Turker (2009). The items of environmental CSR were employed by Mai (2013) and Turker (2009). Firm reputation was determined using a 4-item scale adapted from El-Garaihy et al. (2014). Last, the items for a firm competitive advantage were mainly derived from El-Garaihy et al. (2014), Saeidi et al. (2015). Each item in this study was measured using a 5-point Likert scale.

\subsection{Sample characteristics}

Demographic characteristics of the sample are illustrated in Table 1.869 respondents representing their businesses in Ho Chi Minh City and Binh Duong Province in Vietnam participated in the survey. Ho Chi Minh City and Binh Duong Province are the two most dynamic industrial zones in Vietnam. Businesses in Ho Chi Minh City comprised 543 (62.4\%) of total respondents, whereas businesses in Binh Duong Province comprised 326 (37.6\%). The respondents came from different business types in manufacturing, real estate, trade and service. The respondents were from FDI, public and private sectors. The business size was also varied from small and mediumsized enterprises to large enterprises.

Tab.1 - Sample characteristics. Source: own research

\begin{tabular}{|l|l|l|l|l|l|l|l|l|l|}
\hline \multirow{2}{*}{ Categories } & \multicolumn{3}{|l|}{ Business sector } & \multicolumn{3}{l|}{ Business type } & \multicolumn{2}{l|}{ Business size } \\
\cline { 2 - 10 } & FDI & Public & Private & $\begin{array}{l}\text { Manufac- } \\
\text { turing }\end{array}$ & $\begin{array}{l}\text { Real } \\
\text { Estate }\end{array}$ & $\begin{array}{l}\text { Trade \& } \\
\text { service }\end{array}$ & Small & Medium & Large \\
\hline $\mathrm{n}$ & 286 & 68 & 515 & 345 & 148 & 376 & 512 & 233 & 124 \\
\hline
\end{tabular}

Note: $\mathrm{n}=$ The number of respondents $(\mathrm{n}=869)$

\subsection{Data analysis}

The study used the partial least squares structural equation modelling (PLS-SEM) method, employing SmartPLS version 3.0 to analyse the proposed research model. For data analysis, the two-step approach was applied. Exploratory factor analysis was used to identify internal consistency reliability (CR), convergent validity and discriminant validity. In the first step, this unique statistical technique allowed researchers to examine the validity and reliability of the measurement, thereby identifying whether the values of the variables were valid and reliable and that invalid and unreliable values were not used in the second step. The second step evaluated the relationships among the different constructs of the research model of the present study.

\section{RESULTS}

The test of validity and reliability of reflective constructs was conducted in the first step. CR is measured to internal consistency reliability. Table 2 shows that the CR of all constructs was in a range from .817 to .878 , which was above .7, which satisfied the rule of thumb (Hair et al., 2016). The indicator reliability value was presented by evaluating the statistics of factor loadings. Hair et 
al. (2012) suggested that items with a minimum loading of .6 should be accepted. The reliability of individual items was logically judged because all scales reported loadings that exceeded .6. To access the convergent validity, average variance extracted (AVE) statistics were used; this value exceeded .5 in all constructs, and these values are from .507 to .622 . This finding indicated that the convergent validity of these constructs was satisfactory.

Tab. 2 - Measurement model evaluation. Source: own research

\begin{tabular}{|l|l|l|l|l|l|}
\hline Constructs & No. Items & $\begin{array}{l}\text { Factor } \\
\text { loadings }\end{array}$ & $\begin{array}{l}\text { Cronbach's } \\
\text { Alpha }\end{array}$ & CR & AVE \\
\hline Legal CSR (LEGCSR) & 5 & $.718-.773$ & .789 & .856 & .543 \\
\hline Economic CSR (ECOCSR) & 4 & $.701-.779$ & .723 & .828 & .546 \\
\hline $\begin{array}{l}\text { Philanthropic CSR } \\
\text { (PHICSR) }\end{array}$ & 4 & $.701-.772$ & .716 & .825 & .541 \\
\hline Ethical CSR (ETHCSR) & 5 & $.699-.737$ & .758 & .838 & .508 \\
\hline $\begin{array}{l}\text { Environmental CSR } \\
\text { (ENVICSR) }\end{array}$ & 7 & $.685-.741$ & .838 & .878 & .507 \\
\hline $\begin{array}{l}\text { Firm Reputation } \\
\text { (FIREPU) }\end{array}$ & 3 & $.778-.807$ & .697 & .832 & .622 \\
\hline $\begin{array}{l}\text { Firm Competitive } \\
\text { Advantage (FICOMAD) }\end{array}$ & 4 & $.684-.767$ & .702 & .817 & .528 \\
\hline
\end{tabular}

Fornell-Larcker criterion analysis in PLS-SEM was used to check the discriminant validity. Two procedures were employed to evaluate the discriminant validity of the constructs. The first to be tested was the indicator of cross-loadings. Each opposing construct did not exceed any indicator load (Hair et al., 2012). Second, the square root of the AVE of a single construct (Table 3) should have been greater than the inter-correlations between the constructs and other model constructs. This analysis confirmed the discriminant validity of all constructs. In general, the results of the measurement model in this study were satisfactory, using statistics considered good at measuring reliability and validity (outer loadings, CR, AVE and Fornell-Larcker criterion analysis).

Tab. 3 - Discriminant validity. Source: own research

\begin{tabular}{|l|l|l|l|l|l|l|l|}
\hline & FICOMAD & FIREPU & ECOCSR & ENVICSR & ETHCSR & LEGCSR & PHICSR \\
\hline FICOMAD & .727 & & & & & & \\
\hline FIREPU & .528 & .789 & & & & & \\
\hline ECOCSR & .566 & .470 & .739 & & & & \\
\hline ENVICSR & .517 & .516 & .595 & .712 & & & \\
\hline ETHCSR & .623 & .524 & .669 & .641 & .713 & & \\
\hline LEGCSR & .563 & .470 & .616 & .534 & .642 & .737 & \\
\hline PHICSR & .564 & .503 & .581 & .610 & .664 & .489 & .735 \\
\hline
\end{tabular}

Variance inflation factor (VIF) is used to test the collinearity of indicators. VIF values must be smaller than 5 to avoid collinearity issues (Hair et al.,2012). The values of all factors range from 
1.577 to 2.755 , which are smaller than 5 . Thus, there are no collinearity issues for the data. The standardised root mean (SRMR) of the model was .056, which was a suitable fit assuming the usual cut-off of .08 (Henseler, 2014). The predictive variance of the model was assessed based on the explained variance portion. The results show that the model was able to describe $36.6 \%$ and $50 \%$ of the variances in FIREPU and FICOMAD, respectively. In addition to estimating the $\mathrm{R}^{2}$ magnitude, predictive relevance was incorporated as an additional assessment for model fit. The Stone-Geisser Q2 (cross-validated redundancy) value was calculated to measure the predictive relevance by employing a blindfolding procedure performed in PLS. Q ${ }^{2}$ value greater than zero illustrates the predictive relevance of the path model. Table 4 shows that the predictive relevance of this model for all constructs was considerably higher than zero; hence, all dependent variables in the model have predictive relevance. As a result, the model displayed an acceptable fit and high predictive relevance.

Tab. 4 - Results of $\mathrm{R}^{2}$ and $\mathrm{Q}^{2}$ value. Source: own research

\begin{tabular}{|l|l|l|}
\hline Construct & $\mathrm{R}^{2}$ Value & $\mathrm{Q}^{2}$ Value \\
\hline FICOMAD & .500 & .247 \\
\hline FIREPU & .366 & .213 \\
\hline
\end{tabular}

Non-parametric bootstrapping was applied with 2,000 replications to test the structural model. Table 5 presents the structural model that resulted from the PLS analysis. For business reputation, the predictors were confirmed to have positive and direct effects on business reputation, particularly legal CSR $(\beta=.147, \mathrm{p}<0.01)$, ethical CSR $(\beta=.139, \mathrm{p}<0.05)$, philanthropic CSR $(\beta$ $=.180, \mathrm{p}<0.001)$ and environmental CSR $(\beta=.202, \mathrm{p}<0.001)$. However, the effect of economic $\operatorname{CSR}(\beta=.061, \mathrm{p}>0.05)$ was negative and not significant. Therefore, H3, H5, H7 and H9 were supported, but H1 was not supported. Further, predictors such as economic CSR $(\beta=.124, \mathrm{p}<$ $0.01)$, legal CSR $(\beta=.174, \mathrm{p}<0.001)$, ethical CSR $(\beta=.212, \mathrm{p}<0.001)$ and philanthropic CSR $(\beta=.160, \mathrm{p}<0.001)$ were shown to have positive and direct effects on a business competitive advantage, whereas environmental CSR did not $(\beta=020, \mathrm{p}>.0 .05)$. Further, the positive and direct effect of business reputation $(\beta=.187, \mathrm{p}<0001)$ on a business competitive advantage was also presented. Thus, H2, H4, H6, H8 and H11 were supported, but H10 was not supported. In general, all the paths were significant except for two (H1 and H10).

Tab. 5 - Path coefficient and hypothesis testing. Source: own research

\begin{tabular}{|l|l|l|l|l|}
\hline Hypothesis & Relationship & Path Coefficient & P-values & Decision \\
\hline H1 & ECOCSR $\rightarrow$ FIREPU & .061 & .199 & Not supported \\
\hline H2 & LEGCSR $\rightarrow$ FIREPU & .147 & .001 & Supported \\
\hline H3 & ETHCSR $\rightarrow$ FIREPU & .139 & .014 & Supported \\
\hline H4 & PHICSR $\rightarrow$ FIREPU & .180 & .000 & Supported \\
\hline H5 & ENVICSR $\rightarrow$ FIREPU & .202 & .000 & Supported \\
\hline H6 & ECOCSR $\rightarrow$ FICOMAD & .124 & .001 & Supported \\
\hline H7 & LEGCSR $\rightarrow$ FICOMAD & .174 & .000 & Supported \\
\hline
\end{tabular}




\begin{tabular}{|l|l|l|l|l|}
\hline H8 & ETHCSR $\rightarrow$ FICOMAD & .212 & .000 & Supported \\
\hline H9 & PHICSR $\rightarrow$ FICOMAD & .160 & .000 & Supported \\
\hline H10 & ENVICSR $\rightarrow$ FICOMAD & .020 & .599 & Not supported \\
\hline H11 & FIREPU $\rightarrow$ FICOMAD & .187 & .000 & Supported \\
\hline
\end{tabular}

\section{DISCUSSION}

Previous studies found that CSR execution as a strategy for pursuing reputation, in the long term, will bring a competitive advantage for firms. Because of the recent level of stakeholder pressure on the social and environmental responsibilities of companies, the successful promotion of CSR strategies in developing countries is critical. Understanding the outcomes of CSR implementation is essential to promoting CSR strategy in companies. This study of CSR implementation offers specific academic implications. First, it enriches the existing literature review of the CSR field by exploring the direct and indirect connections of CSR dimensions, firm reputation and firm competitive advantage. Although each connection was tested and validated in several prior studies, few studies have considered the direct effect of CSR dimensions on competitive advantage. Moreover, empirical evidence about how corporate reputation works as a mediator is sparse. Second, in contrast to Farooq et al. (2014), Park (2019) and Park et al. (2014), the present study is anchored in the perspectives of managers, thereby complementing CSR studies from different stakeholders. The present study aimed to examine the effects of CSR dimensions on firm reputation and firm competitive advantage, a mediating role of reputation on the relationship between CSR and competitive advantage was also discussed. Through the results, the research model was confirmed, identifying how each CSR type affects reputation and competitive advantage, along with the mediation effect of reputation. The empirical results of this study in a developing context supported the resource-based theory since there was a positive relationship between CSR, reputation and competitive advantage. Competitive advantage is driven and strengthened through the scare and hard to imitate resources such as CSR and reputation. Thus, the findings confirmed the universal belief of the resource-based theory, and the positive findings enrich the existing literature on strategic management.

The results indicated that legal, ethical, environmental and philanthropic CSR practices had different positive effects on reputation. Implementing legal, ethical and philanthropic CSR practices lead to a better reputation which is consistent with the previous studies (Saeidi et al., 2015; Wang \& Berrens, 2015). The legal CSR reflects how firms commit to legal requirements, and ethical CSR reflects the degree of society's expectations on business activities, but not as formal as law requirements (Shah \& Khan, 2019). Philanthropic CSR is a voluntary activity to show commitment to society. The legal, ethical and philanthropic CSR practices will lead to a long-term commitment to society, which easily enhance reputation. The highest effect of environmental CSR on the reputation of firms is consistent with the findings of Khojastehpour \& Johns (2014) nda Park (2019). Khojastehpour \& Johns (2014) suggested that the emergence of phenomena related to the environment (climate change and the utilisation of natural resources) is considered a current trend in society, which has led to the ever-changing social attitudes of stakeholders (customers, employees and government) towards environmental responsibilities of 
firms. Further, the significance of environmental responsibility is one of the exclusive features of manufacturing firms, which accounted for $43.4 \%$ of the surveyed firms. This kind of firms is considered to significantly cause greenhouse gas emissions and environmental pollution. Therefore, once firms can meet these expectations of stakeholders, they can gain a reputation in the market. Notably, although environmental, philanthropic, legal and ethical CSR had significant effects on a firm reputation, economic CSR did not. This finding contrasts with previous studies (Park et al.2014; Wang \& Berrens, 2015). Nevertheless, the finding supported the study of Hanzaee \& Sadeghian (2014), as economic CSR is considered essential business practice, so it does not help firms to build a reputation. From a manager's perspective, economic CSR activities, such as controlling employee productivity or ensuring benefits for employees, are not important drivers to the reputation of firms. Since reputation in this study is more about how stakeholders view a firm, firms' voluntary and ethical activities, such as donating to charities, caring about employees' needs and protecting the environment, are likely to increase firm reputation rather than financial activities. In addition, since making profits for investors or the firms themselves and offering quality products for consumers is a must-have for the existence of every firm, its presence will not affect the reputation of a firm. However, its absence may negatively affect the survival of firms in the long term. Thus, within the proposed model, economic CSR was unearthed as an important determinant of competitive advantage

The results showed that philanthropic CSR had a positive effect on competitive advantage and the finding supports the study of Porter \& Kramer (2003). Philanthropic practices improve the relationship with society and give firms more opportunities to operate and grow. More importantly, employee involvement in philanthropic CSR may shape the perceptions of the firm in the eyes of stakeholders and lead to stakeholders holding more positive impressions of philanthropic firms. This returns to firms through a lower cost of supporting public relations (Chang et al., 2014). Further, once customers notice that firms strive to create benefits for the whole community through charitable programs, such as donating funds, goods and services, they will feel proud of purchasing products of these socially responsible firms and be willing to pay an extra price (Brammer \& Millington, 2008). This may be because by doing this, customers may believe that they can contribute to society and be a part of it. From this perspective, managers should consider accentuating philanthropic activities and raising employees' awareness and encouraging them to participate in charity programs to support the local community.

The finding of a positive relationship between legal CSR and reputation is consistent with the study of Park et al. (2014). This finding suggests that firms performing legal responsibilities will not only maintain their reputation but will also achieve a competitive advantage. Indeed, complying with laws and regulations is considered one of the fundamental requirements in the operation of firms. Violations of law, such as tax evasion, may have a devastating influence on the reputation of a firm and may even leave the firm on the brink of bankruptcy. Also, the results show that ethical CSR had the highest direct effect on competitive advantage. Ethical practices create values for customers, customer satisfaction and result in a good competitive situation (Hossan Chowdhury, 2011). More importantly, managers consider employee needs and wants, and the provision of a friendly and comfortable workplace can make employees happy. As a result, 'happy' employees give rise to productivity and reduce turnover rates (Javed et al., 2020). 
Moreover, these ethical actions can help forge a stronger bond between employees and firms, and thus, can lead to employee engagement in the long term. Although economic CSR does not have an influence on generating reputation, it has a positive effect on competitive advantage, supporting the previous studies (Cegliński \& Wiśniewska, 2016; El-Garaihy et al.,2014). In a competitive market, firms that conduct business activities improving capability and productivity have a higher chance of success than other competitors do and result in a better competitive advantage.

Interestingly, the result indicated that environmental CSR had no direct effect on competitive advantage. This finding is in contrast with the empirical results of previous studies (Yadav et al., 2017; Mishra \& Yadav 2021). Simpson et al. (2004) explained that investment in environmental issues is a cost that could not create values for stakeholders, so it could not lead to competitive advantage. Investing in environmental CSR activities will be costly in the long term. This causes an increase in the costs of manufacturing; hence, an increase in the price of products will make it difficult for firms to compete in the market. Environmental CSR, despite its lack of direct effect on competitive advantage, showed a significant effect on competitive advantage indirectly through building a reputation. In other words, the effects of environmental CSR on a firm competitive advantage were mediated by firm reputation. Managers should increase efforts to meet the expectations of stakeholders through strategies focused on developing environmentally friendly products and environmental campaigns. From the marketing perspective, advertising such environmental efforts can be an effective tactic to build a reputation, and in the long term, gain a competitive advantage. Although the relationship between economic CSR and competitive advantage was not mediated by reputation, the other four relationships were mediated. Reputation not only has a direct effect on competitive advantage but also mediates the relationship between CSR and competitive advantage in general. The direct effects and mediating effects of the relationships investigated in this study. The results indicated it is crucial for firms to gain intangible resources of reputation by implementing CSR practices resulting in competitive advantage.

\section{CONCLUSION}

The study attempted to explain firm reputation and competitive advantage formation for firms that actively practice and promote CSR activities. Its results confirm that firm reputation contributes to the relationship between CSR implementation (except economic CSR) and firm competitive advantage. Further, four of the five dimensions of CSR, except environmental CSR, have a positive direct effect on generating a competitive advantage. The results can be guidelines for firms aiming to achieve a competitive edge in the market. The results suggest that firms should implement CSR as a long-term strategy to gain reputation and competitive advantage. First, managers should establish systematic and well-structured plans and programs for corporate responsibility, considering their effect on reputation. Second, the effects of firm reputation on firm competitive advantage suggest that managers should focus on maintaining and developing a good reputation in the industry for cultivating competitive advantage. Third, to generate competitive advantage, managers should pay greater attention to ethical CSR (concern about the health, safety and wellbeing of employees and benefits for employees via labour and 
rewards policies), legal CSR (complying with laws and regulations), philanthropic CSR (donate and encourage employees to attend to public social welfare) and economic CSR (add value for stakeholders, facilitate the long-term growth of the firm, while meeting the standards set for philanthropic, ethical, environmental and philanthropic practices). These practices help firms to gain competitive advantages.

This study has several notable limitations. Findings may not necessarily be generalisable to other fields. The inferences drawn from a sample may not be fully generalisable to other areas owing to cultural and national differences. Third, the results are based on the perspective of the manager. Therefore, future studies could consider investigating more diversified stakeholder perspectives (employees, customers and investors) from different fields (airlines and hospitality) and areas in Vietnam and other Asian countries with similar economic and infrastructure conditions.

\section{References}

1. Ahn, J., Shamim, A., \& Park, J. (2021). Impacts of cruise industry corporate social responsibility reputation on customers' loyalty: Mediating role of trust and identification. International Journal of Hospitality Management, 92,102706. https://doi.org/10.1016/j.ijhm.2020.102706

2. Ali, I., Ali, M., Grigore, G., Molesworth, M., \& Jin, Z. (2020). The moderating role of corporate reputation and employee-company identification on the work-related outcomes of job insecurity resulting from workforce localization policies. Journal of Business Research, 117, 825-838. https://doi.org/10.1016/j.jbusres.2019.02.060

3. Alvarado-Herrera, A., Bigne, E., Aldas-Manzano, J., \& Curras-Perez, R. (2017). A scale for measuring consumer perceptions of corporate social responsibility following the sustainable development paradigm. Journal of Business Ethics, 140, 243-262.

https://doi.org/10.1007/s10551-015-2654-9

4. Baalbaki, S., \& Guzmán, F. (2016). A consumer-perceived consumer-based brand equity scale. Journal of Brand Management, 23 (3), 229-251. https://doi.org/10.1057/bm.2016.11

5. Barney, J. (1991). Firm Resources and Sustained Competitive Advantage. Journal of Management, 17 (1), 99-120. https://doi.org/10.1177/014920639101700108

6. Bendixen, M., \& Abratt, R. (2007). Corporate Identity, Ethics and Reputation in SupplierBuyer Relationships. Journal of Business Ethics, 76 (1), 69-82.

https://doi.org/10.1007/s10551-006-9273-4

7. Brammer, S., \& Millington, A. (2005). Corporate reputation and philanthropy: An empirical analysis. Journal of Business Ethics, 61 (1), 29-44. https://doi.org/10.1007/s10551-005-7443-4

8. Brammer, S., \& Millington, A. (2008). Does it pay to be different? An analysis of the relationship between corporate social and financial performance. Strategic Management Journal, 29 (12), 1325-1343. https://doi.org/10.1002/smj.714

9. Branco, M. C., \& Rodrigues, L. L. (2006). Corporate Social Responsibility and ResourceBased Perspectives. Journal of Business Ethics, 69 (2), 111-132.

https://doi.org/10.1007/s10551-006-9071-z 
10. Cacioppe, R., Forster, N., \& Fox, M. (2008). A Survey of Managers' Perceptions of Corporate Ethics and Social Responsibility and Actions that may Affect Companies' Success. Journal of Business Ethics, 82 (3), 681-700. https://doi.org/10.1007/s10551-007-9586-y

11. Carroll, A. B. (1991). The pyramid of corporate social responsibility: Toward the moral management of organizational stakeholders. Business Horizons, 34 (4), 39-48.

12. Carroll, A. B. (2016). Carroll's pyramid of CSR: taking another look. International Journal of Corporate Social Responsibility, 1 (1), 1-8. https://doi.org/10.1186/s40991-016-0004-6

13. Carroll, A. B., \& Shabana, K. M. (2010). The Business Case for Corporate Social Responsibility: A Review of Concepts, Research and Practice. International Journal of Management Reviews, 12 (1), 85-105. https://doi.org/10.1111/j.1468-2370.2009.00275.x

14. Cegliński, P., \& Wiśniewska, A. (2016). CSR as a source of competitive advantage: The case study of Polpharma group. Journal of Corporate Responsibility and Leadership, 3 (4), 9-25. https://doi.org/10.12775/JCRL.2016.020

15. Chang, K., Kim, I., \& Li, Y. (2014). The Heterogeneous Impact of Corporate Social Responsibility Activities That Target Different Stakeholders. Journal of Business Ethics, 125 (2), 211-234. https://doi.org/10.1007/s10551-013-1895-8

16. Chun, S., \& Cho, E. (2017). Differentiation strategy, CSR, and real activities earnings management: Evidence from Korea. Journal of Applied Business Research (JABR), 33 (4), 669-692. https://doi.org/10.19030/jabr.v33i4.9988

17. Collier, J., \& Esteban, R. (2007). Corporate social responsibility and employee commitment. Business Ethics: A European Review, 16 (1), 19-33. https://doi.org/10.1111/j.1467-8608.2006.00466.x

18. Creyer, E. H. (1997). The influence of firm behavior on purchase intention: do consumers really care about business ethics? Journal of Consumer Marketing, 14 (6), 421-432. https://doi.org/10.1108/07363769710185999

19. Dahlsrud, A. (2008). How corporate social responsibility is defined: an analysis of 37 definitions. Corporate Social Responsibility and Environmental Management, 15 (1), 1-13. https://doi.org/10.1002/csr.132

20. El-Garaihy, W. H., Mobarak, A. K. M., \& Albahussain, S. A. (2014). Measuring the impact of corporate social responsibility practices on competitive advantage: A mediation role of reputation and customer satisfaction. International Journal of Business and Management, 9 (5), 109-124. https://doi.org/10.5539/ijbm.v9n5p109

21. Farooq, M., Farooq, O., \& Jasimuddin, S. M. (2014). Employees response to corporate social responsibility: Exploring the role of employees' collectivist orientation. European Management Journal, 32 (6), 916-927. https://doi.org/10.1016/j.emj.2014.03.002

22. Fombrun, C. J., Gardberg, N. A., \& Sever, J. M. (2000). The Reputation Quotient SM: A multi-stakeholder measure of corporate reputation. Journal of Brand Management, 7 (4), 241-255. https://doi.org/10.1057/bm.2000.10

23. Fombrun, C. J. (1996). Realizing value from the corporate image. Harvard Business School Press, Boston, MA. 
24. Galbreath, J. (2010). Drivers of corporate social responsibility: The role of formal strategic planning and firm culture. British Journal of Management, 21 (2), 511-525.

https://doi.org/10.1111/j.1467-8551.2009.00633.x

25. Hair Jr, J. F., Hult, G. T. M., Ringle, C., \& Sarstedt, M. (2016). A primer on partial least squares structural equation modeling (PLS-SEM). Sage publications.

26. Hair, J. F., Sarstedt, M., Ringle, C. M., \& Mena, J. A. (2012). An assessment of the use of partial least squares structural equation modeling in marketing research. Journal of The Academy of Marketing Science, 40 (3), 414-433. https://doi.org/10.1007/s11747-011-0261-6

27. Han, H., Yu, J., \& Kim, W. (2019). Environmental corporate social responsibility and the strategy to boost the airline's image and customer loyalty intentions. Journal of Travel \& Tourism Marketing, 36 (3), 371-383. https://doi.org/10.1080/10548408.2018.1557580

28. Han, H., Yu, J., Lee, K. S., \& Baek, H. (2020). Impact of corporate social responsibilities on customer responses and brand choices. Journal of Travel \& Tourism Marketing, 37 (3), 302-316. https://doi.org/10.1080/10548408.2020.1746731

29. Hanzaee, K. H., \& Sadeghian, M. (2014). The impact of corporate social responsibility on customer satisfaction and corporate reputation in automotive industry: Evidence from Iran. Journal of Islamic Marketing, 5 (1), 125-143. https://doi.org/10.1108/JIMA-05-2013-0033

30. He, H., \& Harris, L. (2020). The impact of Covid-19 pandemic on corporate social responsibility and marketing philosophy. Journal of Business Research, 116, 176-182. https://doi.org/10.1016/j.jbusres.2020.05.030

31. Heinberg, M., Ozkaya, H. E., \& Taube, M. (2018). Do corporate image and reputation drive brand equity in India and China? - Similarities and differences. Journal of Business Research, 86, 259-268. https://doi.org/10.1016/j.jbusres.2017.09.018

32. Henseler, J. (2014). Common factor models, composite models, and formative measurement: Their nature, application, and testing. Lecture at University of Seville, Spain

33. Hortoványi, L. (2016). The dynamic nature of competitive advantage of the firm. Advances in Economics and Business, 4 (11), 624-629.

34. Hossan Chowdhury, M. (2011). Ethical issues as competitive advantage for bank management. Humanomics, 27 (2), 109-120. https://doi.org/10.1108/08288661111135117

35. Hur, W. M., Kim, H., \&Woo, J. (2014). How CSR Leads to Corporate Brand Equity: Mediating Mechanisms of Corporate Brand Credibility and Reputation. Journal of Business Ethics, 125 (1), 75-86. https://doi.org/10.1007/s10551-013-1910-0

36. Husted, B. W., \& Allen, D. B. (2007). Strategic corporate social responsibility and value creation among large firms: lessons from the Spanish experience. Long-range planning, 40 (6), 594-610. https://doi.org/10.1016/j.lrp.2007.07.001

37. Islam, T., Islam, R., Pitafi, A. H., Xiaobei, L., Rehmani, M., Irfan, M., \& Mubarak, M. S. (2021). The impact of corporate social responsibility on customer loyalty: The mediating role of corporate reputation, customer satisfaction, and trust. Sustainable Production and Consumption, 25, 123-135. https://doi.org/10.1016/j.spc.2020.07.019 
38. Jamali, D., \& Karam, C. (2018). Corporate Social Responsibility in Developing Countries as an Emerging Field of Study: CSR in Developing Countries. International Journal of Management Reviews, 20 (1), 32-61. https://doi.org/10.1111/ijmr.12112

39. Javed, M., Rashid, M. A., Hussain, G., \& Ali, H. Y. (2020). The effects of corporate social responsibility on corporate reputation and firm financial performance: Moderating role of responsible leadership. Corporate Social Responsibility and Environmental Management, 27 (3), 1395-1409. https://doi.org/10.1002/csr.1892

40. Khojastehpour, M., \& Johns, R. (2014). The effect of environmental CSR issues on corporate/ brand reputation and corporate profitability. European Business Review, 26 (4), 330-339. https://doi.org/10.1108/EBR-03-2014-0029

41. Kim, K. H., Kim, M., \& Qian, C. (2018). Effects of Corporate Social Responsibility on Corporate Financial Performance: A Competitive-Action Perspective. Journal of Management, 44 (3), 1097-1118. https://doi.org/10.1177/0149206315602530

42. Kim, M., Yin, X., \& Lee, G. (2020). The effect of CSR on corporate image, customer citizenship behaviors, and customers' long-term relationship orientation. International Journal of Hospitality Management, 88, 102520. http://dx.doi.org/10.1016/j.ijhm.2020.102520

43. Kowalczyk, R., \& Kucharska, W. (2020). Corporate social responsibility practices incomes and outcomes: Stakeholders' pressure, culture, employee commitment, corporate reputation, and brand performance. A Polish-German cross-country study. Corporate Social Responsibility and Environmental Management, 27 (2), 95-615. http://dx.doi.org/10.1002/csr.1823

44. Lantos, G. P. (2001). The boundaries of strategic corporate social responsibility. Journal of Consumer Marketing, 18 (7), 595-632. http://dx.doi.org/10.1108/07363760110410281

45. Mai, N. P. (2013). Implementing corporate social responsibility towards sustainable development: a case study of SMEs in Thanh Hoa province. VNU Journal of Science: Economics and Business, 29 (5E), 67-80.

46. McWilliams, A., Siegel, D. S., \& Wright, P. M. (2006). Corporate social responsibility: Strategic implications. Journal of management studies, 43 (1), 1-18. https://doi.org/10.1111/j.1467-6486.2006.00580.x

47. Melo, T., \& Garrido-Morgado, A. (2012). Corporate reputation: A combination of social responsibility and industry. Corporate Social Responsibility and Environmental Management, 19 (1), 11-31. http://dx.doi.org/10.1002/csr.260

48. Miles, M. P., \& Covin, J. G. (2000). Environmental marketing: A source of reputational, competitive, and financial advantage. Journal of Business Ethics, 23 (3), 299-311. https://doi.org/10.1023/A:1006214509281

49. Mishra, P., \& Yadav, M. (2021). Environmental capabilities, proactive environmental strategy and competitive advantage: A natural-resource-based view of firms operating in India. Journal of Cleaner Production, 291, 125249.

50. Muller, A., \& Kräussl, R. (2011). Doing good deeds in times of need: A strategic perspective on corporate disaster donations. Strategic Management Journal, 32 (9), 911-929.

https://doi.org/10.1002/smj.917 
51. Nelling, E., \& Webb, E. (2009). Corporate social responsibility and financial performance: the "virtuous circle" revisited. Review of Quantitative finance and accounting, 32 (2), 197-209. https://doi.org/10.1007/s11156-008-0090-y

52. Nyuur, R. B., Ofori, D. F., \& Amponsah, M. M. (2019). Corporate social responsibility and competitive advantage: A developing country perspective. Thunderbird International Business Review, 61 (4), 551-564. https://doi.org/10.1002/tie.22065

53. Öberseder, M., Schlegelmilch, B. B., \& Murphy, P. E. (2013). CSR practices and consumer perceptions. Journal of Business Research, 66 (10), 1839-1851. https://doi.org/10.1016/j.jbusres.2013.02.005

54. Park, E. (2019). Corporate social responsibility as a determinant of corporate reputation in the airline industry. Journal of Retailing and Consumer Services, 47, 215-221. http://dx.doi.org/10.1016/j.jretconser.2018.11.013

55. Park, J., Lee, H., \& Kim, C. (2014). Corporate social responsibilities, consumer trust and corporate reputation: South Korean consumers' perspectives. Journal of Business Research, 67 (3), 295-302. https://doi.org/10.1016/j.jbusres.2013.05.016

56. Porter, M. E., \& Kramer M. R. (2006). Strategy and Society: The Link Between Competitive Advantage and Corporate Social Responsibility. Harvard Business Review, 84 (12), 78-92.

57. Porter, M. E., \& Kramer, M. R. (2003). Corporate philanthropy: Taking the high ground. Foundation strategy group, 13, 1-12.

58. Saeed, M. M., \& Arshad, F. (2012). Corporate social responsibility as a source of competitive advantage: The mediating role of social capital and reputational capital. Journal of Database Marketing \& Customer Strategy Management, 19 (4), 219-232.

59. Saeidi, S. P., Sofian, S., Saeidi, P., Saeidi, S. P., \& Saaeidi, S. A. (2015). How does corporate social responsibility contribute to firm financial performance? The mediating role of competitive advantage, reputation, and customer satisfaction. Journal of Business Research, 68 (2), 341-350. https://doi.org/10.1016/j.jbusres.2014.06.024

60. Shah, S. S. A., \& Khan, Z. (2019). Corporate social responsibility: a pathway to sustainable competitive advantage? International Journal of Bank Marketing, 38 (1), 159-174. https://doi.org/10.1108/ijbm-01-2019-0037

61. Simpson, M., Taylor, N., \& Barker, K. (2004). Environmental responsibility in SMEs: does it deliver competitive advantage? Business strategy and the environment, 13 (3), 156-171. https://doi.org/10.1002/bse.398

62. Turker, D. (2009). Measuring corporate social responsibility: A scale development study. Journal of Business Ethics, 85 (4), 411-427. http://dx.doi.org/10.1007/s10551-008-9780-6

63. Van Beurden, P., \& Gössling, T. (2008). The Worth of Values - A Literature Review on the Relation Between Corporate Social and Financial Performance. Journal of Business Ethics, 82 (2), 407-424. http://dx.doi.org/10.1007/s10551-008-9894-x

64. Walker, K., Zhang, Z., \& Ni, N. (2019). The mirror effect: corporate social responsibility, corporate social irresponsibility and firm performance in coordinated market economies and liberal market economies. British Journal of Management, 30 (1), 151-168. https://doi.org/10.1111/1467-8551.12271 
65. Wang, Y., \& Berens, G. (2015). The impact of four types of corporate social performance on reputation and financial performance. Journal of Business Ethics, 131 (2), 337-359.

https://doi.org/10.1007/s10551-014-2280-y

66. Wernerfelt, B. (1995). The resource-based view of the firm: Ten years after. Strategic Management Journal, 16 (3), 171-174. https://doi.org/10.1002/smj.4250160303

67. Yadav, P. L., Han, S. H., \& Kim, H. (2017). Sustaining competitive advantage through corporate environmental performance. Business Strategy and the Environment, 26 (3), 345-357. https://doi.org/10.1002/bse.1921

68. Yu, H. C., Kuo, L., \& Kao, M. F. (2017). The relationship between CSR disclosure and competitive advantage. Sustainability Accounting, Management and Policy Journal, 12 (4), 642-653. https://doi.org/10.1108/SAMPJ-11-2016-0086

69. Zhang, Q., Cao, M., Zhang, F., Liu, J., \& Li, X. (2020). Effects of corporate social responsibility on customer satisfaction and organizational attractiveness: A signaling perspective. Business Ethics: A European Review, 29 (1), 20-34.

http://dx.doi.org/10.1111/beer.12243

70. Zhu, Y., Sun, L. Y., \& Leung, A. S. (2014). Corporate social responsibility, firm reputation, and firm performance: The role of ethical leadership. Asia Pacific Journal of Management, 31 (4), 925-947. http://dx.doi.org/10.1007/s10490-013-9369-1

\section{Contact information}

Assoc. Prof. Ngoc Khuong Mai

School of Business, International University, Ho Chi Minh City, Vietnam

Vietnam National University, Ho Chi Minh City, Vietnam

Vietnam

Email:mnkhuong@bcmiu.edu.vn

ORCID: 0000-0002-0527-3046

An Khoa Truong Nguyen, PhD candidate (corresponding author)

School of Business, International University, Ho Chi Minh City, Vietnam

Vietnam National University, Ho Chi Minh City, Vietnam

Thu Dau Mot University, Vietnam

Vietnam

Email:truongan@tdmu.edu.vn

ORCID:0000-0003-2107-5506

Thanh Thuy Nguyen, Undergraduate

School of Business, International University, Ho Chi Minh City, Vietnam

Vietnam National University, Ho Chi Minh City, Vietnam

Vietnam

Email: thanbthuy6093@gmail.com 